ge replaced when they retire to rest by this apparatus, so that the foot may be constantly kept in the position desired without moving during sleep. It is likewise very applicable in other deformities, such as talipes varus, equinus, valgus, and calcaneus, flat-foot, \&c., whether dating from birth or acquired after birth, when in connexion with it a plate of the form needed by each individual case is used. When it is a question of children who have not yet walked my apparatus is also useful, but I have kept more in mind those who have already walked for the reason that they are the most difficult to cure, and this is because with $\mathrm{my}$ contrivance they cannot place the foot on the ground, while with others known to me when patients are allowed to walk if they let the weight of the body fall on the point operated upon they may possibly do so in a manner liable to cause them injury. When my apparatus is employed the foot of the patient will be always held in a desirable position, and if the operation be not crowned with complete success the blame cannot be attributed to any defect in the position of the deformed member.
DIABETES AND NEUROTIC INHERITANCE.

BY J. C. M. GIVEN, M.D. LoND.,

LSSISTANT PHYSICIAN TO THE LIVERPOOL SKIN AND CANCER HOSPITAL.

THE following pedigree, which I obtained when attending one of the cases of diabetes set out, is interesting as an ascertain.

$\underset{\begin{array}{c}\text { Male, } \\ \text { spasmodic asthma. }\end{array} \mid \begin{array}{c}\text { Female, } \\ \text { Male, } \\ \text { healthy. }\end{array}}{=}$ died from scarlet fever

\begin{tabular}{|c|c|c|c|}
\hline $\begin{array}{c}\text { Male, } \\
\text { themiplegic, } \\
\text { married. }\end{array}$ & $\begin{array}{c}\text { I } \\
\text { Female, } \\
\text { healthy, } \\
\text { married. }\end{array}$ & $\begin{array}{c}\text { Male, } \\
\text { epileptic } \\
\text { and chronic } \\
\text { alcoholic. }\end{array}$ & $\begin{array}{c}\text { Female, } \\
\text { died from } \\
\text { diabetes. }\end{array}$ \\
\hline all healthy. & healthy. & & \\
\hline
\end{tabular}

\section{SOME EXCEPTIONAL CASES OF MALIGNANT DISEASE.}

BY HERBERT SNOW, M.D. LOND., SURGEON TO THE CANCER HOSPITAL, BROMPTON.

CASE 1. Simultaneous development of carcinoma in both parotid glands ; excision; subsequent ovariotomy for cyst with twisted pedicle; recovery.-On Aug. 9th, 1895, a swarthy young woman aged thirty-four years, married, with a child aged sixteen months, was admitted to hospital with symmetrical tumours below each ear. That on the left was as large as a hen's, and that on the right as a pigeon's, egg, and not dissimilar in shape. They were of eighteen months' duration, had commenced therefore during pregnancy, and nearly at the same time, withont any other obvious cause. There was no family history of cancer and no symptom in the least indicative thereof. The only complaint was earache. The general health was fairly good and there was a total absence of emaciation or of pain about the new growths, which felt smooth and exactly like an ordinary lymphoma, though slightly more elastic. At the lower extremity of the left was a round lump thought to be a distinct gland, but which subsequently proved to be a lobular projection from the primary tumour. Both were increasing quickly in bulk and caused considerable disfigurement. Upon incision they showed to the naked eye the greyish granular base commonly indicative of malignancy; they were firmly embedded in the parotid tissue and were dissected out with difficulty. The facial nerve passed directly through the left, and its division could not be avoided. Under the microscope the appearances were pronounced by Mr. Plimmer, pathologist to the hospital, to be typical of malignant lymph-gland disease (lympho-carcinoma) - a view in which I concurred. With a few minute cysts containing a milky fluid were large masses of small lymphoid cells, proliferating exuberantly and eroding the surrounding tissues. Presumably, therefore, the disease originated in one of the parotid lymph-glands. While in bed it was discovered almost accidentally that there was also an abdominal example of how diabetes mellitus may be inherited and also of the fact now generally acknowledged that it may alternate with various neuroses. In this family of four generations (the fourth generation being only infants) there are three cases of diabetes mellitus, one of spasmodic asthma, two of chronic alcoholism, one of epilepsy, and one of hemiplegia the exact nature of which I could not

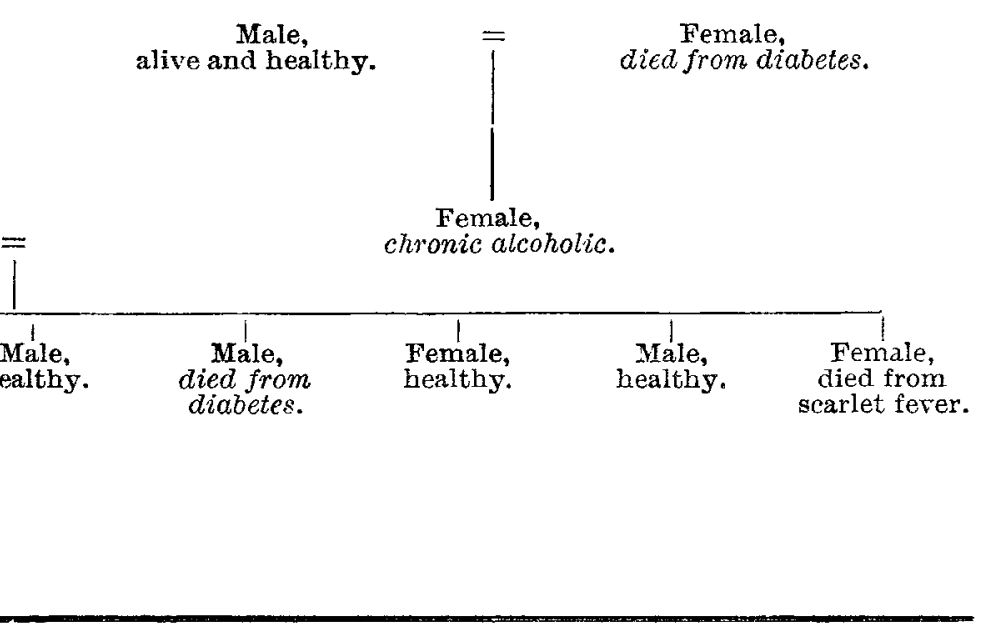

tumour which had so far given rise to no symptoms. It was as large as a child's head and was extremely mobile, feeling like a tense cyst. It had been noticed for six or seven months. The patient was discharged for domestic reasons on Nov. 7 at her own request. She sought readmission, however, on Nov. 21st, with severe abdominal pain and tenderness, the temperature rising to $103.6^{\circ} \mathrm{F}$. Two days subsequently laparotomy was performed and a cyst of the left ovary with a long twisted pedicle was removed. Apparently the torsion was of some weeks' duration, though no symptoms had arisen previously to the first discharge from hospital. The cyst-wall was anteriorly adherent to the parietes and was there gangrenous, with blackish contents ; the parietes were infiltrated and almost gristly. A favourable recovery ensued. The patient was seen well on Feb. 4th, 1896, with no indication of recurrence in the parotids or elsewhere.

CASE 2. Simultaneous derelopment of carcinoma in the uterus and mamma.-A woman aged sixty-two years, a widow, was admitted to hospital on Jan. 8th, 1896. A prominent livid boss of encephaloid carcinoma, soft and freely movable, was visible at the upper and outer part of the left breast. Its duration was three months, it was of rapid growth and subsequent to a blow. The axillary glands were slightly enlarged. There was no family history of cancer. The patient was worn and emaciated. She was armitted for operation. A complaint of vaginal discharge led to digital examination, and it was then found that there was also malignant disease of the uterine cervix, that organ being firmly fixed in the pelvis ; there was a deeply excavated ulcer, with fetid discharge, and infiltration of the surrounding tissues. So far as could be ascertained it had commenced simultaneously with the breast-lesion. The woman remains (Feb. 6th) an in-patient in an incurable ward, the idea of operative interference having been abandoned.

CASE 3. Malignant disease of both oraries; excision; recovery. A woman aged thirty-two years, single, was admitted to hospital on Aug. 13th, 1895. A large fluctuating tumour, noticed for two months. distended the aboomen. The menses were regular. There were emaciation and shooting pain on the left side. The mother had her breast excised two years previously for cancer; the mother's mother had "cancerated" (sic) tumour of the small bowel. Cntil a month previously the patient had been a laundress, a calling 